\title{
A PROTOTYPE OF AN OPEN HARDWARE-BASED AUTOMATIC PHOTOGRAPHIC CAMERA TO MONITOR SNOW COVER EVOLUTION AND WEATHER PHENOMENA IN THE CONTEXT OF THE FROZEN GROUND MONITORING: PERMARDUINO- CAMERA
}

\author{
M.A. DE PABLO \\ Depto. de Geología, Geografía y Medio Ambiente. Universidad de Alcalá \\ C. DE PABLO S. \\ Especialista en electrónica. Madrid \\ M. RAMOS \\ Departamento de Física y Matemáticas. Universidad de Alcalá \\ M. PRIETO \\ Departamento de Automática. Universidad de Alcalá
}

Recibido: $29 / 12 / 2015$

Aceptado: 25/05/2016

ABSTRACT: The study of permafrost and active layer thermal behavior require continuous monitoring of ground temperatures as well as other additional parameters, including snow cover, because of its isolation effect when the thickness is enough high. Typical monitoring stations from Thermal State of Permafrost (TSP) network includes the air temperature monitoring to derive snow thickness. Moreover, its low snow deep accuracy, this device return data from one place each time. To know and study the snow onset, offset, duration and distribution is sometimes required and the use of automatic digital photographic cameras contribute to have an adequate approach. However, commercial automatic cameras are expensive. For that reason, we developed a robust, simple, low-cost, open hardware-based (Arduino) prototype of an automatic camera to take pictures and store them into an SD card $(2 \mathrm{~Gb})$ that allows more than 4 years of hourly continuous image acquisition. The device is powered by a small solar cell that charges a li-po battery. The firmware allows a detailed monitoring of the device and error detection, and configure the camera for its own. We used a TTL serial JPEG camera with CMOS $1 / 4$ inch sensor with $480 \times 640$ pixels in resolution, with NTCS video capacity to allow real-time camera focus. The camera acquires images on panchromatic and near IR band. The fully operative prototype has been tested in Antarctica, and it was finally installed in Byers Peninsula in order to study the snow cover evolution at the Limnopolar Lake CALM site. In this work we present the prototype and its firmware to allow others to develop their own cameras to monitor snow cover or any other phenomenological parameter.

KEY WORDS: Frozen ground; Snow cover; Digital automatic camera; Instrumentation.

PROTOTIPO DE CAMMARA FOTOGRÁFICA AUTOMÁTICA BASADA EN

HARDWARE ABIERTO PARA MONITORIZAR LA EVOLUCIÓN DE LA CUBIERTA

DE NIEVE Y FENÓMENOS METEOROLÓGICOS EN EL CONTEXTO DE LA

VIGILANCIA DEL SUELO CONGELADO: PERMARDUINO-CÁMARA

Polígonos. Revista de Geografia, 28 (2016); 161-181 
RESUMEN: El estudio permafrost y la capa activa requiere de la medición continuada de la temperatura del terreno, y de otros parámetros adicionales, incluyendo el espesor de la capa de nieve debido al efecto aislante que puede tener. Las estaciones típicas de estudio térmico del permafrost (TSP en inglés), incluye la medida de la temperatura del aire a diferentes alturas para derivar el espesor aproximado de la capa de nieve. Más allá de la baja resolución de este método, estos termonivómetros sólo facilitan datos de un punto del territorio. Sin embargo, conocer y estudiar la evolución y distribución de la cubierta de nieve requiere en muchos casos del uso de cámara fotográficas automáticas, con el problema del alto coste de las mismas. Por ello, hemos desarrollado un dispositivo robusto, simple, de bajo coste, y basado en el uso de hardware libre (Arduino), capaz de tomar fotografias y almacenarlas en una tarjeta de memoria SD $(2 \mathrm{~Gb})$ con capacidad para más de 4 años de actividad continuada. Este dispositivo está alimentado por una placa solar y una batería Li-po. La cámara usada permite obtención de imágenes JPEG mediante el uso de un sensor CMOS de 1/4 de pulgada e imágenes de hasta 480x640 píxeles de resolución. Además, dispone de salida NTCS de video que facilita las tareas de enfoque en el campo. La cámara adquiere imágenes en el rango pancromático e infrarrojo cercano. El prototipo funcional del dispositivo fue probado en la Antártida, e instalado finalmente en la península Byers para estudiar la evolución de la capa de nieve en el emplazamiento CALM Limnopolar Lake. En este trabajo se presenta el prototipo y su configuración para permitir a otros desarrollar sus propias cámaras para el seguimiento de la cubierta de nieve u otros fenómenos meteorológicos.

PALABRAS CLAVE: Suelos congelados, Nieve, Cámara digital automática, Instrumentación.

\section{INTRODUCTION}

The study of permafrost and active layer plays an important role on both periglacial environments knowledge and climate evolution monitoring (e.g., HINKEL, 1997; HARRIS et al., 2001; TURNER et al., 2007; RAMOS et al., 2008, 2009; VIEIRA et al., 2010; DE PABLO et al., 2013, 2014a; BOCKHEIM et al., 2013). In fact, the monitoring of permafrost and active layer is one of the common research topics on different environments, including high mountain, polar and subpolar (e.g., BROWN et al., 2000; MATSUOKA and HUMLUM, 2003; NELSON et al., 2004; BOCKHEIM, 2006; MATSUOKA, 2006; NELSON and SHILOMANOV, 2009; VIEIRA et al., 2010). Research networks, like Ground Temperature Network -Permafrost (GTN-P), developed different monitoring protocols to allow the ground thermal monitoring and active layer thickness measurement such as the Thermal State of Permafrost (TSP) and Circumpolar Active Layer Monitoring (CALM), respectively (e.g., BROWN et al., 2000; MATSUOKA and HUMLUM, 2003; NELSON et al., 2004; MATSUOKA, 2006). Monitoring ground temperatures allow both to observe yearly evolution of the temperatures and long-standing trends. The second case requires decadal of continuous monitoring but it is the most interesting in the context of climate warming. However, the first case allows continuous data analysis to observe and establish short-time thermal behaviors, although to really understand the thermal evolution of the ground requires to monitor other parameters what could influence on the ground temperature. Then, air and surface temperatures 
and snow cover, are the most common additional variables required to monitor, such as proposed at the TSP protocol. On the other hand, more complete monitoring stations include also radiation flux, precipitation, wind speed and other meteorological variables. In general, the use of digital cameras to monitor weather events are not common in these TSP monitoring stations. High costs and relatively low resolution do not compensate, in general, the qualitative information provided by the pictures. Only when to determine timely meteorological events is required to understand the thermal events or general thermal behavior observed in the data, or when the data from a monitoring station require to be spatially extended, a digital automatic camera is required. Because the TSP stations usually do not monitor snow cover deep, but air temperature at different height in a mast from which data could be derived snow cover deep by different procedures (e.g., DANBY and HIK, 2007; LEWKOWICZ, 2008). Then, the use of cameras also provides a way to check the derived snow deep, that it is really relevant when trying to understand the ground thermal behavior. In fact, the snow cover plays an important role on the ground thermal evolution due to its isolation effect (e.g., GOODRICH, 1982, ZHANG et al., 2003; ZHANG, 2005) or its contribution to runoff and groundwater during the snow melting season (e.g., DEWALLE and RANGO, 2008). However, the snow cover deep and duration changes areally, and the snow cover deep derived at a TSP station does only provide punctual information. Then, when trying to understand the local variability of the ground thermal behavior between different nearest TSP stations, or of the active layer thickness in a CALM site, the analysis of the snow onset, offset, duration and thickness is required not punctually, but areally. To solve this, multiple snow deep monitoring devices are required, or one of them together with an automatic digital camera could be used in homogeneous terrains to provide a good approach to these parameters of the snow cover.

However, both, the installation of multiple snow deep monitoring devices and commercial digital cameras result on expensive monitoring stations what which goes against the philosophy of the TSP stations of simplicity and low costs in order to allow the research teams to extend the network to have more monitoring sites at many as possible periglacial environments. To avoid this problem, we develop a robust low-cost and low maintenance device on the use of open-hardware electronics (Arduino, http://arduino.cc/), and a miniature digital camera sensor. This device, that we named PERMARDUINOCAMERA, could be included or be an independent element of a PERMARDUINO station, a low-cost, open hardware based station to monitor ground, surface and air temperatures and snow cover deep (de Pablo et al., 2014b, 2015). PERMARDUINO-CAMERA reduces a $90 \%$ the costs of a 
standard commercial outdoor scientific camera with the same resolution, contributing to allow to extend the use of digital phenomenological cameras inside the different monitoring research stations (mainly TSP and CALM).

Here we present the first prototype we developed, showing and explaining its characteristics: camera resolution, memory capacity, and maintenance tasks under cold and harsh weather conditions. We show the electronic circuit of the prototype in order to allow other colleagues to produce their own devices as well as to modify by their own our design in order to fit their needs. The necessary firmware is also showed and explained to make possible to others to easily introduce modifications. Finally, after to show the results of the first test of few days of activity in a monitoring site in Byers Peninsula, Livingston Island, Antarctica, in January 2015, we explain the future possible modification could be applied to the device to improve it characteristics.

\section{PERMARDUINO CAMERA}

\section{II.1. General design}

PERMARDUINO-CAMERA device (FIGURE 1) is a prototype of a phenomenological camera complimentary to both the monitoring devices of a TSP station and a CALM site (e.g., BROWN et al., 2000; MATSUOKA and HUMLUM, 2003; NELSON et al., 2004; MATSUOKA, 2006). This device results from our efforts on the PERMARDUINO project to develop low-costs, low maintenance and open hardware-based ground thermal monitoring stations (DE PABLO et al., 2014b, 2015), based on our experience on the maintenance of this type of monitoring stations in South Shetland Island, Antarctica. The design of the PERMARDUINO-CAMERA tried to provide the next characteristics to the device: (1) low cost, (2) simple design, (3) easy construction, (4) easy use, (5) easy installation, (6) simple maintenance, (7) easily configurable, (8) robust to weather conditions, and (9) small in size and light in weight). Those characteristics are shared with the PERMARDUINO thermal monitoring station (DE PABLO et al., 2014b).

The PERMARDUINO-CAMERA device includes a CMOS sensor in order to take pictures automatically that are stored into a SD card, and it is powered by a small battery that is charged with a solar panel. The camera is controlled by a microcontroller and use a real time clock and a battery and its charger. The complete device, except the solar cell, is housed in a 160x110x70 mm waterproof semi-rigid plastic case that has been adapted to be installed in a (wood) mast. A hole has been open in the front of the case and protected with double glass (this one used to protect digital cameras LCD screens) to allow the camera to take the pictures without expose it to the rush environmental 
conditions. Except the solar cell and its connection cable, no external elements are required.

Figure 1. Picture of the PERMARDUINO-CAMERA mounted in a $2 \mathrm{~m}$ high mast installed in Byers Peninsula, Antarctica, and detail of the house opened for configuration and SD memory card replacement.

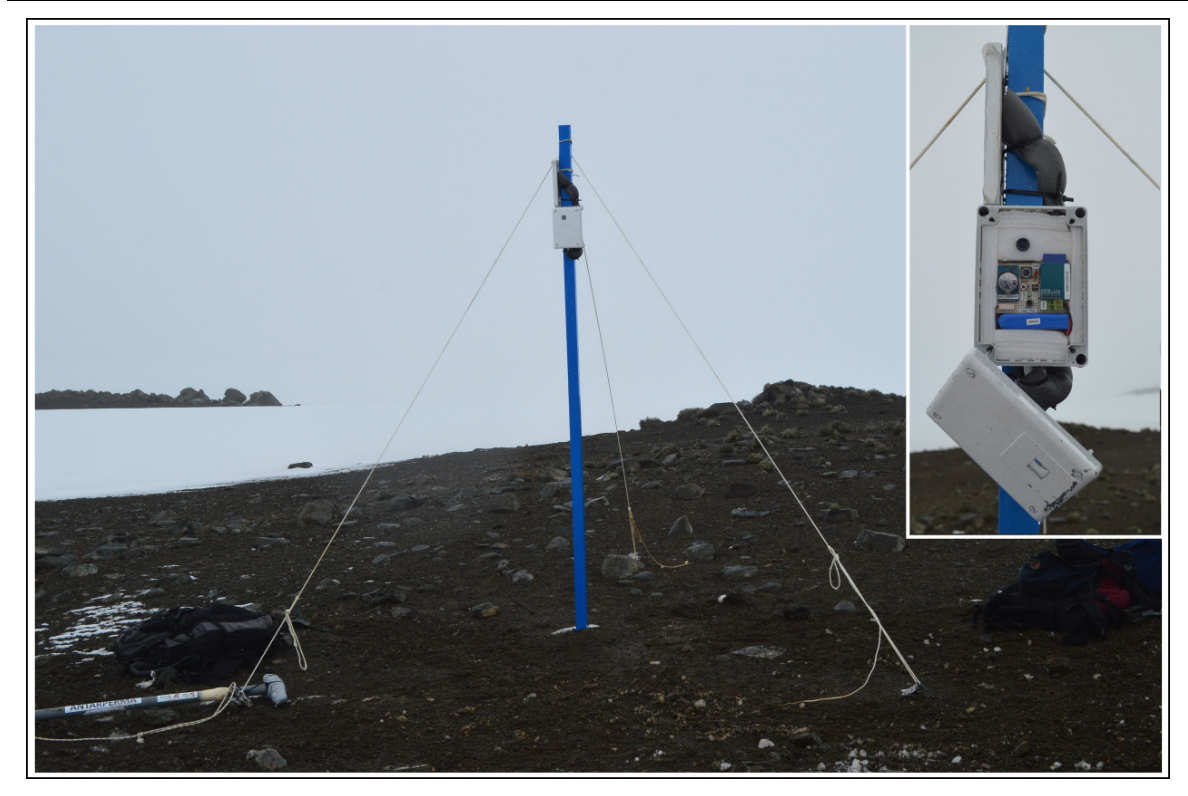

SOURCE: The authors

\section{II.2. Core, power and electronics}

PERMARDUINO-CAMERA device (FIGURE 2) is based on Arduino: an open-hardware board that uses a microcontroller to control both digital and analogical inputs and outputs (http://arduino.cc/), easily coded in C language, and extended by adding stackable shields or any kind of electronic devices. PERMARDUINO-CAMERA use an Arduino Uno board, equipped with and ATMega328P microcontroller (from ATMEL) with $32 \mathrm{~Kb}$ of flash memory, 14 digital inputs/outputs, 6 analog inputs, and provide I2C, UART and ICSP communications. The board is also equipped with a $16 \mathrm{MHz}$ crystal oscillator, a USB connection, a power jack, and an ICSP header (https://www.arduino.cc/en/Main/ArduinoBoardUno). It operated at $5 \mathrm{~V}$ and could be powered by an external supply of 6 to $20 \mathrm{~V}$. Serial communications over USB are able thanks to a FTDI chip on the board, what made possible virtual com port to software on the computer to program it by the use of Arduino Integrated Development Environment (IDE) freeware 
(https://www.arduino.cc/en/Main/Software), such as we will see below. Arduino Uno board, is about $50 \mathrm{~mm}$ wide and $63 \mathrm{~mm}$ long, and it contains 2 arrays of female pins that provide direct connection to the inputs/outputs of the microcontroller.

We used these characteristics to connect a commercial shield to charge a Lithium polymer-based battery: Energy shield (FIGURE 2) by Seed Studio (http://www.seedstudio.com). This shield allows to charge Li-po batteries by the use of solar cells. This shield contains its own arrays of female pins to allow to stack other shield or direct access to inputs/outputs in the Arduino board. PERMARDUINO-CAMERA is powered by a $3.7 \mathrm{~V}$ and $6,000 \mathrm{mAh} \mathrm{Li-}$ po battery combine with a $3 \mathrm{~W}$ solar cell $(5 \mathrm{~V}$ and $660 \mathrm{~mA}), 180 \times 140 \times 20 \mathrm{~mm}$ in size.

Figure 2. (Left) Elements of the PERMARDUINO-CAMERA device: (1) Arduino Uno board, (2) Energy shield, to charge a (3) $3.7 \mathrm{~V}$ lithium-polymer battery by a $3 W$ solar panel, (4) camera shield that includes a (5) SD memory card holder, and (6) the NTCS jpeg serial camera. (Right) These elements already stacked and adjusted into a waterproof electronics housing box, including vibrations and thermal isolator.

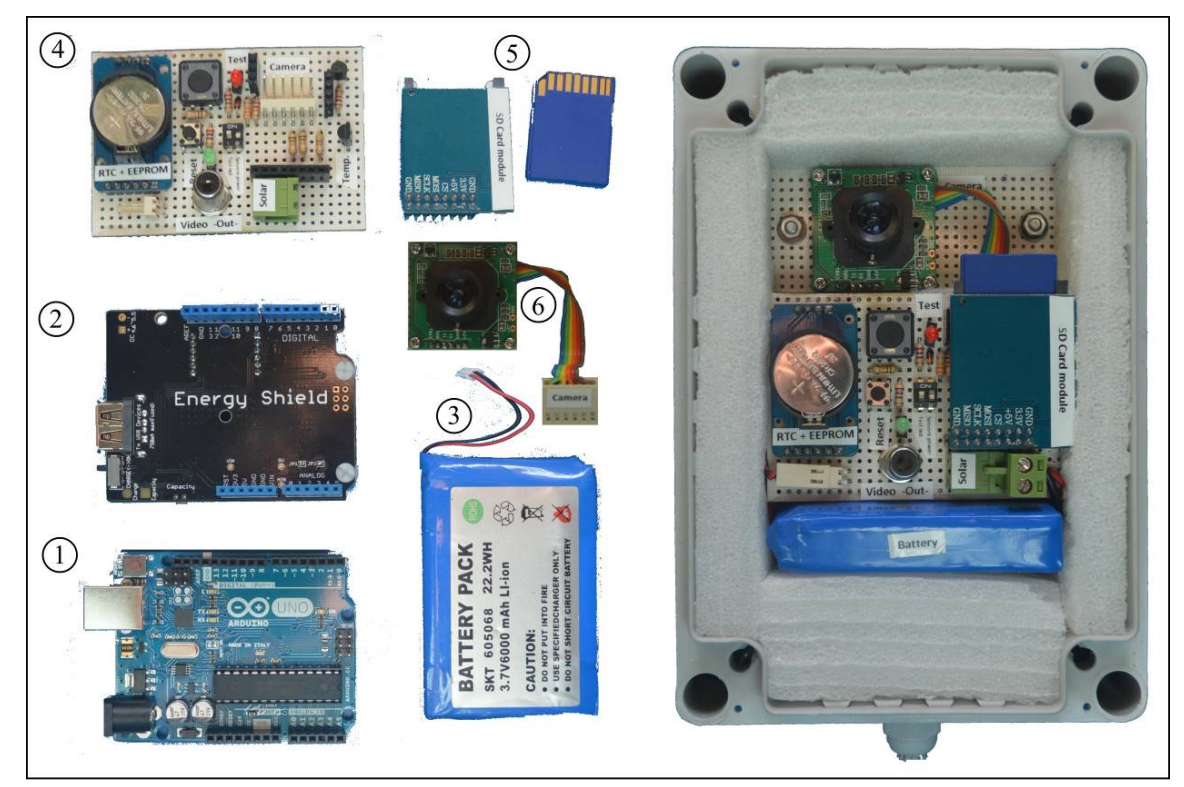

SOURCE: The authors

The used camera is a JPEG camera with a CMOS $1 / 4$ inch sensor that provides a configurable resolution, with a maximum resolution of VGA 480x640 
pixels (0.7 Mpixels), with progressive scan mode, automatic white balance and exposure adjustment, and $60^{\circ}$ of vision angle. The sensor does not have IR filter, so, it captures data in the visible plus near IR. This camera is mounted in a $32 \times 32 \mathrm{~mm}$ module, and it provides NTCS video capacities, that allow to adjust focus in real time by connecting to a device with $\mathrm{AV}$-in ports or to a computer by means of any standard video-to-USB connector. This camera communicates with Arduino board by a configurable 38400 to 115200 baud by TTL serial port.

To acquire the pictures at regular times, a board with a DS1337 Real Time Clock (RTC) chip to remain accurate timing and a $3 \mathrm{~V}$ backup coin cell battery, was required. This RTC allow to program alarms that advise the Arduino board to activate, take the picture, save it and deactivate again. Pictures, in JPEG format, are stored into a $2 \mathrm{~Gb}$ SD memory card (FAT 16 format) slot at a SD card module connected to the Arduino board by ISCP communications protocol. The pictures files names are controlled by firmware and they are named with an 8 characters long code based on the acquirement date including year(Y), month (M), date (D) and hour (H) (YYMMDDHH.jpeg; e.g., 15011513.jpeg is the picture acquired in January 15, 2015 at 13:00h). In this way, images could be easily later organized by filename in a computer. The memory card we use have enough capacity to store about 40,000 pictures (it is about 1,600 days of monitoring with hourly acquirement of pictures of 50 $\mathrm{Kb}$ in size), although it additionally stores an ASCII file, excel-compatible ASCII file, CSV formatted, with device control data, such as date, time, inner temperature, device temperature, picture name, detected error, etc.

The, a $2 \mathrm{~Gb}$ SD ensure about 4 year of continuous monitoring at full resolution and device capacities. In fact, device temperature, a DS18B20 digital temperature sensor has been used, what only required a pull-up 4.7 kohms resistor. For maintenance reasons during working operations, our device includes a 3 $\mathrm{mm}$ in diameter red led what is switched by another digital pin of the Arduino board controlled by firmware to show the user when the device is measuring. This led is connected to a micro-switch what could be turned off by the user to save battery during the stand alone period of work of the device, and turned on during testing and maintenance operations. We will see latter that this led is used by firmware to show error detection. A pushbutton was also added in order to allow the user to check the device status (device activity and error on execution time). An additional small pushbutton has been added to the shield for reseat purposes (for example after an error detection, or SD card connection). Other small pushbuttons have been added to reset the device. 
All the electronics components (TABLE 1) were soldered into a PCB board by simple circuits (FIGURE 3 ). To constitute a shield stackable to the Arduino and Energy shields. The size of this shield is the same than the Arduino board, $50 \times 63 \mathrm{~mm}$, although it does not include the camera that is connected to this board by a parallel cable due to space requirements inside the case. One all the elements are stacked, the electronics part of the device is a module and small, light, robust and compact block of 50x63x60 mm in size, allowing enough space inside the case to hold the battery and the camera.

Figure 3. Components and circuit of the camera shield (element '4' in Figure 2), stackable to the Arduino Uno board (and compatible), what constitute the main development of this project, together with the corresponding firmware.

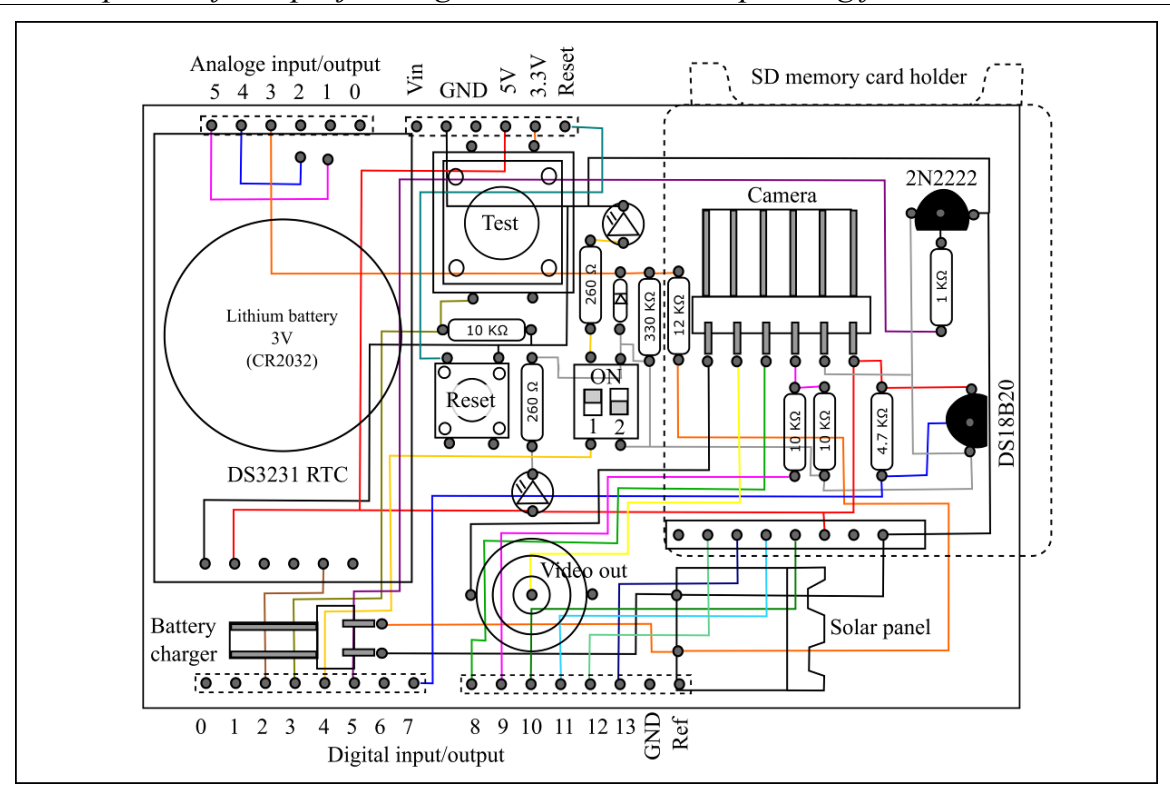

SOURCE: The authors

Table 1. Electronics components required for the PERMARDUINO-CAMERA device

\begin{tabular}{cl|cl}
\hline$\#$ & \multicolumn{1}{c|}{ Component } & $\#$ & \multicolumn{1}{c}{ Component } \\
\hline 1 & Arduino Uno board & 2 & Resistor $260 \Omega$ \\
\hline 1 & Energy Shield & 1 & Resistor $1 \mathrm{~K} \Omega$ \\
\hline 1 & 3.7V 6000 mAh Li-po battery & 1 & Resistor $4.7 \mathrm{~K} \Omega$ \\
\hline 1 & Protoboard (2.54 mm spaced) & 3 & Resistor $10 \mathrm{~K} \Omega$ \\
\hline 1 & SD card holder & 1 & Resistor $12 \mathrm{~K} \Omega$ \\
\hline 1 & 2Gb SD card & 1 & Resistor $330 \mathrm{~K} \Omega$ \\
\hline 1 & NTCS jpeg serial camera & 1 & Diode Zener $5 \mathrm{~V}$ \\
\hline 1 & DS3231 RTC & 1 & Transistor $2 \mathrm{~N} 2222$ \\
\hline
\end{tabular}




\begin{tabular}{ll|ll}
\hline 1 & DS18B20 temperature sensor & 1 & Led Red $3 \mathrm{~mm}$ \\
\hline 1 & 2 pins connector (male \& female) & 1 & Led Green $3 \mathrm{~mm}$ \\
\hline 1 & 6 pins connector (male \& female) & 1 & Micro-switch \\
\hline 1 & 2 pins connector (male \& female) & 1 & Video connector \\
\hline 1 & Array of male pins connector & 1 & Push button mini \\
\hline 1 & Array of female pins connector $(40)$ & 1 & Push button normal \\
\hline SOURCE: The author
\end{tabular}

SOURCE: The authors

\section{II.3. Firmware}

The PERMARDUINO-CAMERA device is controlled by a firmware written in $C$ language by the use of Arduino IDE version 1.6.5 (available for Windows, Mac and Linux operative systems). The freeware Arduino IDE allows the firmware compilation and its upload to the microcontroller in the Arduino board by means of an USB standard cable. The firmware contents are limited by the amount of free memory available in the microcontroller $(30 \mathrm{~Kb})$, used for both firmware and volatile memory during the program running. However, this memory is enough to run a program to control the image acquirement and its save into an SD card.

The firmware (APPENDIX 1) is divided into different sections 4 different sections what run in sequence by the microcontroller: (1) device configuration, that contains information required by the microcontroller to assigns tasks to each digital/analogical pin as well as to read additional procedures: (a) libraries definition, (b) analogue pins definition, (c) digital pins definition, (d) variables definition, (e) constants definition, (f) log and images files definition, and (g) libraries configuration; (2) Device initialization, that (i) power on the camera and sensors, (j) check the RTC, (k) check the SD card, (l) check the data file, $(\mathrm{m})$ write the datafile header is required, (n) check camera and its configuration, and (o) check the temperature sensor and configure; (3) main device operation, that (s) read the present time, (p) check for error -if the pushbutton was pressed, (q) take a picture and read the sensors -if the pushbutton was not pressed and it is the measurement time, (r) save the data, (s) changes to low-power consumption and $(t)$ sleep during the waiting period or the pushbutton is pressed; and (4) Procedures, that contains tasks required in any moment during the device configuration (Section 2) or the main program running (Section 3), like sensor reading, data saving, device checking, etc. Section 1 and 2 run only one time after a startup or a reset (by pushing the small pushbutton in the device shield); Section 3 runs into an infinite loop until an error, a reset or a power down; and Section 4 runs only when called from any of the other sections. 
This firmware could be modified by each user in the Arduino IDE and uploaded as many times as required to the board to fit the user requirements. And could be also modified to add other sensors, increase/reduce the measurements frequency, change the datafile data stamp, etc. The content, design, and workflow of the firmware depend on the user requirements, the used sensors and hardware stacked and connected to the Arduino board. Extensive information about how to wire devices to Arduino, and how to write the corresponding firmware could be found in the Arduino forum webpage as well as in many books (e.g., MARGOLIS, 2011; BANZI, 2011; EVANS, 2011; TIMMIS, 2011; MONKS, 2012; GLETZ and DI JUSTO, 2012; DI JUSTO and GERTZ, 2012; BAYLE, 2013; BLUM, 2013). On the other hand, the use of different sensors and electronics elements could require long codes, what are usually already available such as libraries what reduce the lines of code required to be write to the user to prepare the firmware.

\section{FIRST TESTS AND PRELIMINARY RESULTS}

Although a 6 months-long testing period was applied to the device in the laboratory, in order to test the prototype under real cold, rough and harsh weather conditions, the device was installed between December 25th 2014 and January 3rt 2015, at the Spanish Antarctic Station «Gabriel de Castilla» in Deception Island (South Shetland Archipelago), Antarctica $\left(62^{\circ} 58^{\prime} 38^{\prime \prime} \mathrm{S}\right.$, $\left.60^{\circ} 40^{\prime} 33^{\prime \prime} \mathrm{W}\right)$. During this period, we examined the device behavior and tried to detect any problem in the electronics, firmware and housing. Due to the excellent results in spite of the cold, windy and snowy conditions, in January 2015, finally we installed the first prototype of PERMARDUINO-CAMERA device in its definitive emplacement in Byers Peninsula, Livingston Island, Antarctica, in early 2015, during the Spanish Antarctic Campaign (FIGURE 4).

The device was installed in a low slope terrain at the shore of the Limnopolar Lake $\left(62^{\circ} 38^{\prime} 59.7^{\prime \prime} \mathrm{S}, 61^{\circ} 06^{\prime} 09.5^{\prime \prime} \mathrm{W}\right)$. This site was selected because from this site there are a complete view of the Limnopolar Lake CALM site that we monitor since 2009 (DE PABLO et al., 2010, 2013, 2014a), and where we observed an increase on the snow cover that is affecting the thermal behavior of the ground (DE PABLO et al., 2016, submitted). We already have a commercial automatic digital camera, but, although it has the same resolution (480x640 pixels), it is further from the CALM site since it is shared with other project that want to monitor the Limnopolar Lake water level and snow cover evolution (e.g., CAMACHO et al., 2014).

After its installation in its final emplacement in a $2 \mathrm{~m}$ height wood mast ensured by 3 cord clamps, we focused it with the help of a laptop and a video recorder software. We leaved the device working for few days meanwhile we 
completed different tasks in the TSP and CALM site at the Limnopolar Lake inside the view field of the camera. Few days later, and before to leave the site and the instrumentation for one year, we checked how it was working. The device recorder pictures as expected (FIGURE 4) without any problem in spite of the cold and windy conditions. During the sunny days, no condensation was registered in the pictures due to the glass that isolate the camera from the environment. However, since the camera was placed pointing to the west, some of the images captured the Sun, saturating partially the images, but without disturbing image of the rest of the scene, and the images are perfectly valid. In any case, reflects or flares were not recorded in the images.

Figure 4. Examples at full resolution (480x640 pixels) and thumbnails of the images acquired by the camera in January 2015 once it was installed in Byers Peninsula, Antarctica, to take pictures (hourly) of the A25 CALM-S site.

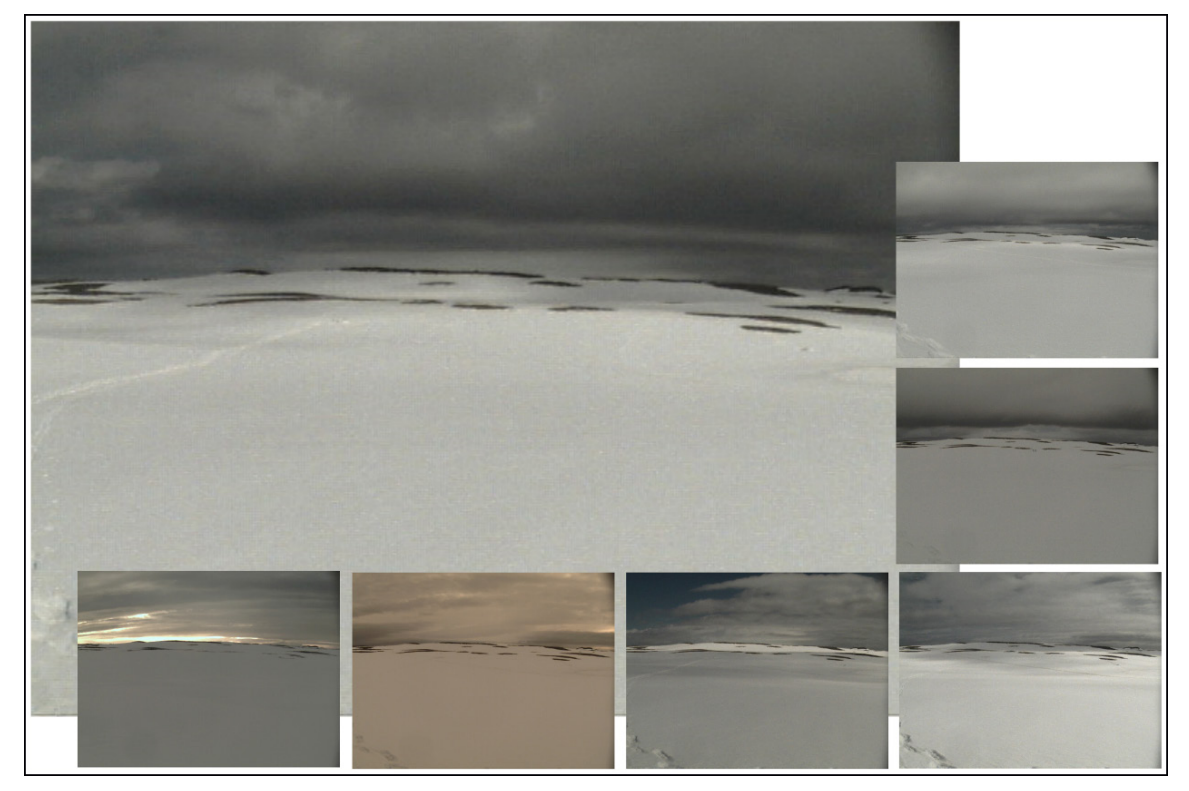

SOURCE: The authors

In spite of the short daytime duration in polar latitudes, we decided to leave the camera configured to take a picture each hour, also during the night, in order to check the consume under real low luminosity conditions to charge the batteries, as well as under the lower temperatures on nighttime, and memory card space. 


\section{CONCLUSIONS}

The PERMARDUINO-CAMERA is part of the PERMARDUINO project to develop an automatic device to monitor permafrost and active layer following the TSP and CALM international protocols. This project is based on the use of open hardware. A functional prototype of PERMARDUINOCAMERA device is presented here. It is an automatic digital photographic camera to take pictures in cold and harsh weather conditions to replace expensive commercial ones, or, at least, to allow the installation of multiple of those by lower price $t$ better monitor the snow cover and other meteorological phenomena. In our case, we develop it to help us to monitor the snow cover evolution and its spatial distribution in order to understand the spatial distribution of active layer thickness in a CALM site in Byers Peninsula, Antarctica.

PERMARDUINO-CAMERA use a TTL serial JPEG VGA 480x640 pixel in resolution camera provided by a CMOS $1 / 4$ inch sensor to acquired pictures in the panchromatic and near IR band with an angle vision of $60^{\circ}$. This camera is connected to our shield stackable to the Arduino Uno (and compatible) board, and an Energy shield to changer by a solar cell a 3.7V li-po battery. The shield contains all the electronics required to connect the camera to a screen to see video on real time to focus the camera, as well as a SD memory card holder where the images and auxiliary data are stored. The device is programmed, by the use of $\mathrm{C}$ language in Arduino IDE, to take pictures hourly, although it could be easily configurable the users by the modification of the firmware we provided here.

The design of PERMARDUINO-CAMERA device tried to provide the next characteristics to the station: (1) low cost, (2) easy design, (3) easy construction, (4) high accuracy in data measurement, (5) easy use, (6) easy installation, (7) simple maintenance, (8) easily configurable, (9) robust to weather conditions, and (10) small in size and light in weight.

The simple design and the low knowledge requirements on electronics and programming make this device a perfect solution for researches who want to develop their own experiments and automatic digital cameras to monitor weather phenomena (among other) on periglacial environments.

\section{ACKNOWLEDGEMENTS}

Authors want to thank to the Arduino Team for the development of Arduino open-hardware project, a way to open the technology to the society, and to the Arduino user's community for their help and collaborations to improve PERMARDUINO-CAMERA code. We also want to than to the Spanish Polar Committee, The Spanish Polar Research Program, and the whole crew of the 
«Juan Carlos I» Spanish Antarctic Station for their help to develop the fieldtrip in Byers Peninsula, Livingston Island, Antarctica. We also want to thank to Cayetana Recio for her help during the camera installation in Antarctica.

This project was partially supported by PERMASNOW (CTM2014-52021R), ANTARPERMA (CTM2011-15565-E), PERMAPLANET (CTM200910165E), PERMAMODEL (POL2006-01918), and PERMATHERMAL projects from the Ministry of Economy and Competitiveness, and the Ministry of Education and Science, Government of Spain.

\section{REFERENCES}

BANZI, M. (2011): Getting started with Arduino. O'Reilly Media, Inc.

BAYLE, J. (2013): C programming for Arduino. O'Reilly Media, Inc.

BLuM, J. (2013): Exploring Arduino: Tools and Techniques for Engineering Wizardry. O'Reilly Media, Inc. BROwN, J.; NELSON, F.E.; and HINKEL, K.M. (2000): «The circumpolar active layer monitoring (CALM) program research designs and initial results». Polar Geography, 3, 165-258.

BOCKHEIM, J.G. (2006): «Permafrost distribution in the southern circumpolar region and its relation to the environment: a review and recommendations for further research». Permafrost and Periglacial Processes, 6, 27-45.

Bockheim, J.; VieIRA, G.; Ramos, M.; LóPez-Martínez, J.; Serrano, E.; GUGLIELMIN, M.; WILHELM, K.; and NIEUWENDAM, A. (2013): «Climate warming and permafrost dynamics in the Antarctic Peninsula region». Global and Planetary Change, 100, 215-223. doi: 10.1016/j.gloplacha.2012.10.018.

Camacho, A.; Villaescusa, J.A.; Rochera, C.; and Jørgensen, S.E. (2014): «Modeling the response of the planktonic microbial community to warming effects in maritime antarctic lakes: Ecological implications». Developments in Environmental Modelling, 26(9). 231-250.

DANBY, R. and HIK, D. (2007): «Responses of white spruce (Picea glauca) to experimental warming at subsurface alpine treeline». Global Change Biology, 13, 437451.

DE PABlo, M.A.; DE PABlo, C.; and RAMOS, M. (2014b): «A prototype of an open hardware-based device for active layer and frozen ground monitoring: PERMARDUINO». 4th European Conference on Permafrost. Évora (Portugal). Abstracts, 444.

de Pablo, M.A.; De Pablo, C.; and Ramos, M. (2015): «Improvements on PERMARDUINO prototype device for active layer and permafrost thermal monitoring, and automatic digital camera development». VI Congreso Ibérico de la International Permafrost Association. Valladolid, Spain. Abstracts, 23.

DE PABLO, M.A.; RAMOS, M.; VIEIRA, G.; and QueSADA, A. (2010): «A new CALMS site on Byers Peninsula, Livingston Island, Antarctica». In: Ambientes Periglaciares, Permafrost y Variabilidad Climática: II Congreso Ibérico de la International Permafrost Association, edited by: BLANCO, J.J.; DE PABlo, M.A.; and RAMOS, M.; Servicio de Publicaciones de la Universidad de Alcalá, Alcalá de Henares, $153-159$. 
de Pablo, M. A.; Blanco, J. J.; Molina, A.; Ramos, M.; Quesada, A.; and VieIRA, G. (2013): «Interannual active layer variability at the Limnopolar Lake CALM site on Byers Peninsula, Livingston Island, Antarctica». Antarctic Science, 25, 167 180. doi: 10.1017/S0954102012000818.

DE PABlo, M.A.; RAmOs, M. and MolinA, A. (2014a): «Thermal characterization of the active layer at the Limnopolar Lake CALM-S site on Byers Peninsula (Livingston Island), Antarctica». Solid Earth, 5. 721-739.

DE PABlo, M.A.; RAmos, M. and MolinA, A. (2016): «Snow cover evolution at the Limnopolar Lake CALM-S site on Byers Peninsula, Livingston Island, Antarctica, 2009-2014». Catena. In press

DeWalle, D. and Rango, A. (2008): Principles of Snow Hydrology. New York: Cambridge University Press. 428 pp. ISBN 978-0-521-82362-3.

Di Justo, P. and GERTZ, E. (2012): Atmospheric monitoring with Arduino. O'Reilly Media, Inc.

Evans, B. (2011): Beginning Arduino programming. Apress Inc.

GERTZ, E. and di Justo, P. (2012): Environmental monitoring with Arduino. O'Reilly Media, Inc.

GOODRICH, L.E. (1982): «The influence of snow cover on the ground thermal regime». Canada Geotechnical Journal, 19, 421 - 432.

HARris, C.; HAEBerli, W.; VONDER MÜHLl, D.; and KING, L. (2001): «Permafrost monitoring in the high mountains of Europe: the PACE project in the global context». Permafrost and Periglacial Processes, 12(1), 3-11.

HINKEL, K.M. (1997): «Estimating seasonal values of thermal diffusivity in thawed and frozen soils using temperature time series». Cold Regions Science and Technology, 26, 1-15.

LEWKOWICZ, A. G. (2008): «Evaluation of miniature temperature-loggers to monitor snowpack evolution at mountain permafrost sites, northwestern Canada». Permafrost and Periglacial Processes, 19, 323-331. doi: 10.1002/ppp.625

MARGOLIS, M. (2011): Arduino cookbook(2nd Edition). O’Reilly Media, Inc.

MATSUOKA, N. (2006): «Monitoring periglacial processes: towards construction of a global network». Geomorphology, 80, 20-31.

MATSUOKA, N. and Humlum, O. (2003): «Monitoring periglacial processes: new methodology and technology». Permafrost and Periglacial Processes, 14, 299 303.

Monks, S. (2012): Programming Arduino: Getting started with sketches. McGrawHill.

Nelson, F.E.; Shiklomanov, N.I.; Hinkel, K. and Christiansen, H. (2004): «Introduction: the Circumpolar Active Layer Monitoring Network (CALM) workshop and CALM II program». Polar Geography, 28, 253-266.

NELSON, F.E. and SHIKLOMANOV, N.I. (2009): «The Circumpolar Active Layer Monitoring Network-CALM III (2009-2014): long-term observations on the "Climate-Active Layer-Permafrost System'”». En BLANCO, J.J.; DE PABLO, M.A. and RAMOS, M. (eds.) Ambientes periglaciares, permafrost y variabilidad Climática: II Congreso Ibérico de la International Permafrost Association. Alcalá de Henares: Servicio de Publicaciones de la Universidad de Alcalá, 9-14. 
Ramos, M.; Hasler, A.; VIEIRA, G.; Gruber, S. and HAUCK, C. (2009): «Setting up boreholes for permafrost thermal monitoring on Livingston Island in the Maritime Antarctic». Permafrost and Periglacial Processes, 20, 57-64.

Ramos, M.; Vieira, G.; Blanco, J.J.; Gruber, S.; HaucK, C.; Hidalgo, M.A. and TOME, D. (2008): «Thermal active layer monitoring in two different sites on Livingston Island during the last seven years: a comparative study». In Proceedings of the Ninth International Conference on Permafrost, Fairbanks, Alaska. Fairbanks, AK: University of Alaska, Institute of Northern Engineering, 1463-1467.

TIMMIS, H. (2011): Practical Arduino engineering. Apres Inc.

Turner, J.; LACHLAN-CoPe, T.A.; COlwell, S.; MARShall, G.J. and CONNERlley, W.M. (2007): «Significant warming of the Antarctic winter troposphere». Science, 131, 1914-1917.

Vieira, G.; Bockheim, J.; Guglielmin, M.; BAlKS, M.; Abramov, A.; BOelhouwers, J.; CANNONE, N.; GANZERT, L.; GILICHINSKY, D.A.; GOTYACHKIN, S.; LÓPEZ-MARTÍNEZ, J.; MEIEKLEJOHN, I.; RAFFI, R.; RAMOS, M.; Schaefer, C.; Serrano, E.; Simas, F.; Sletten, R. and Wagner, D. (2010): «Thermal state of permafrost and active-layer monitoring in the Antarctic: advances during the International Polar Year 2007-2009». Permafrost and Periglacial Processes, 21, 182-197.

ZHANG, T. (2005): «Influence of the seasonal snow cover on the ground thermal regime: An overview». Rev. Geophys.; 43. RG4002. doi:10.1029/2004RG000157

Zhang, T.; BARry, R.G.; KNOWLes, K.; Ling, F.; and ARMSTRONG, R.L. (2003): «Distribution of seasonally and perennially frozen ground in the Northern Hemisphere». In: Proceedings of the 8th International Conference on Permafrost, 2125 July 2003, Zurich, Switzerland [Phillips, M.; S.M. Springman, and L.U. Arenson (eds.)]. A.A. Balkema, Lisse, the Netherlands, pp. 1289-1294.

\section{APPENDIX 1: COMMENTED PERMARDUINO-CAMERA (VER- SION 1.0) FIRMWARE, READY TO COPY AND PASTE ON ARDUINO IDE.}

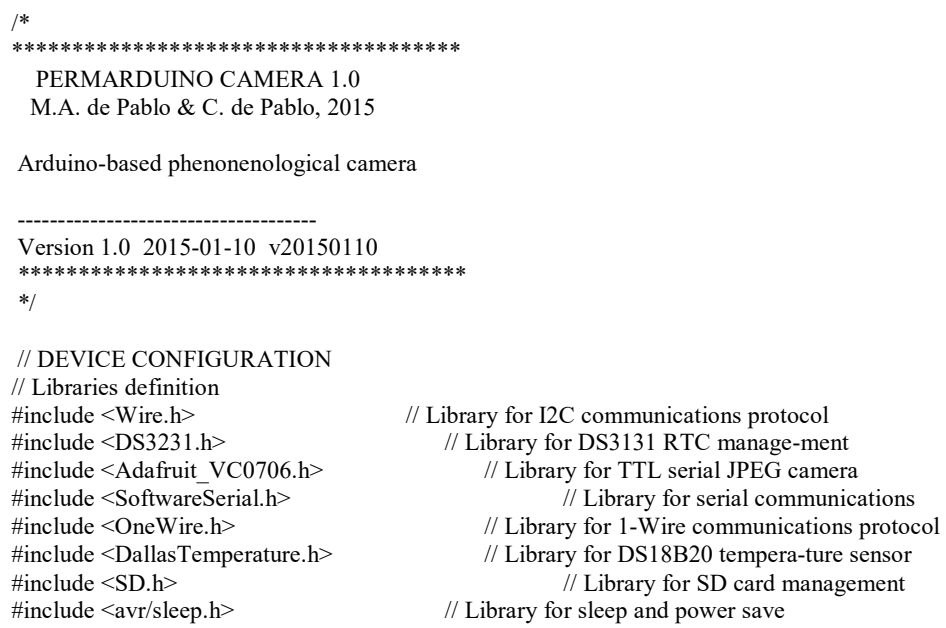




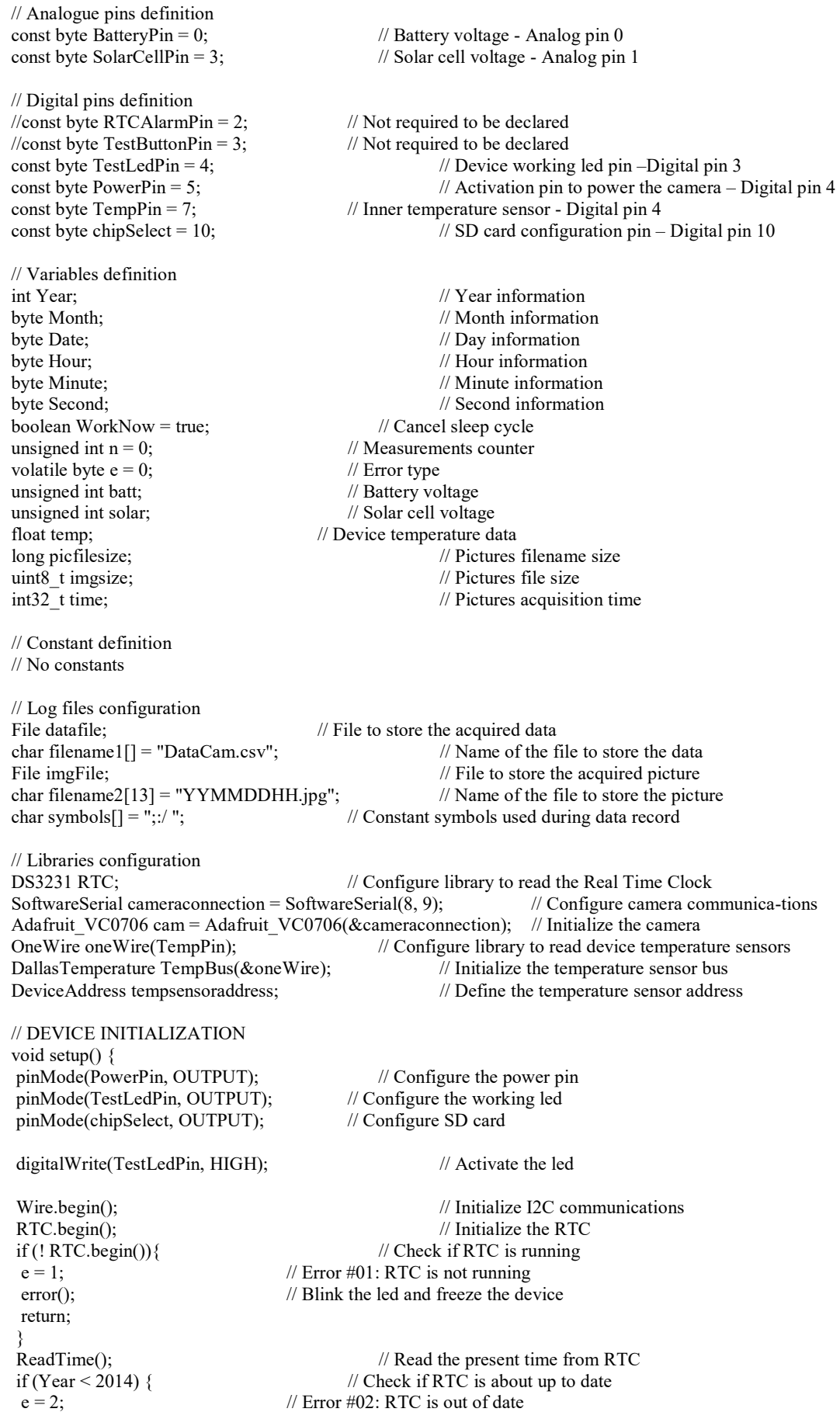




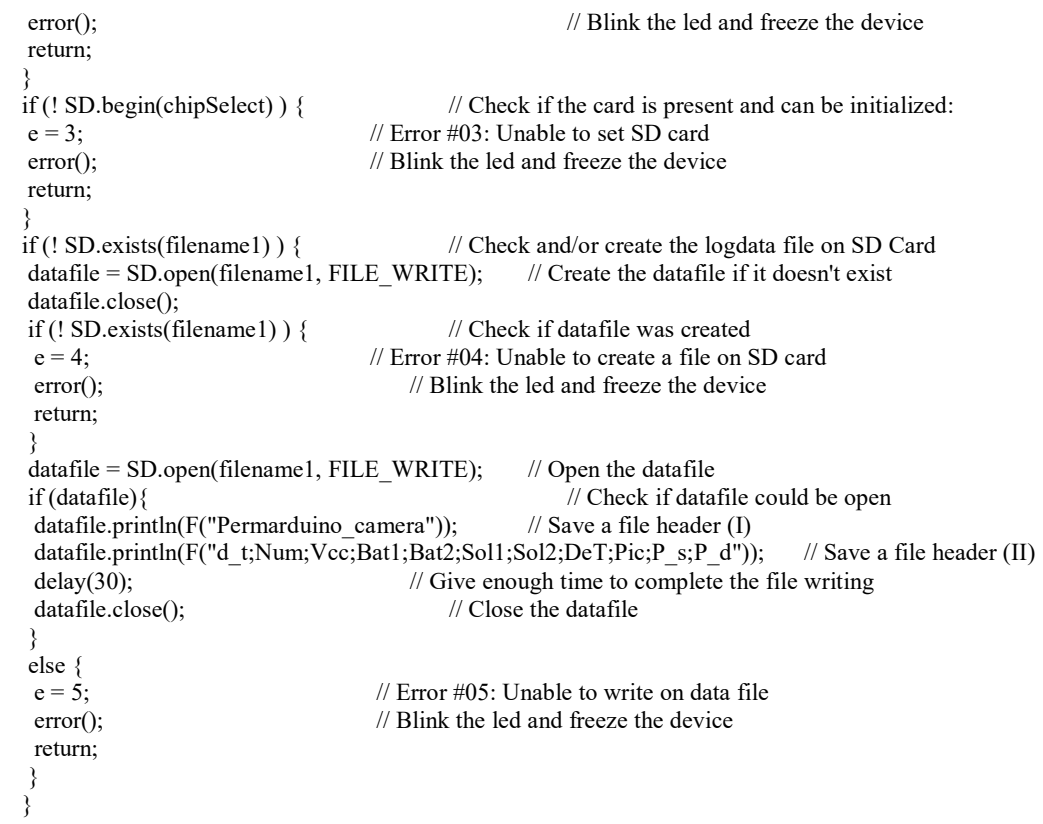

error(); $\quad$ // Blink the led and freeze the device

// Check if the card is present and can be initialized:

// Error \#03: Unable to set SD card

// Delay to ensure the signal stabilization from sensors // Initialize the camera

// Error \#06: Unable to initialize the camera

// Blink the led and freeze the device

digitalWrite(PowerPin, LOW);

digitalWrite(TestLedPin, LOW); delay (500);

CheckDevice();

RTC.enableInterrupts(EveryHour);

// Delay to ensure the signal stabilization from sensors // Try to take a picture

// Error \#08: Unable to take a picture

// Blink the led and freeze the device

// Initialize the Temperature sensor on OneWire bus

// Delay to ensure the signal stabilization from sensors

// Configure temperetature sensor address // Read the temperature sensor address

); // Set DS18B20 sensor precision to 12 bits

// Turn off the power for sensors

// Turn off test led

// Check other not fundamental error

// Set the working alarm for the device (hourly) 


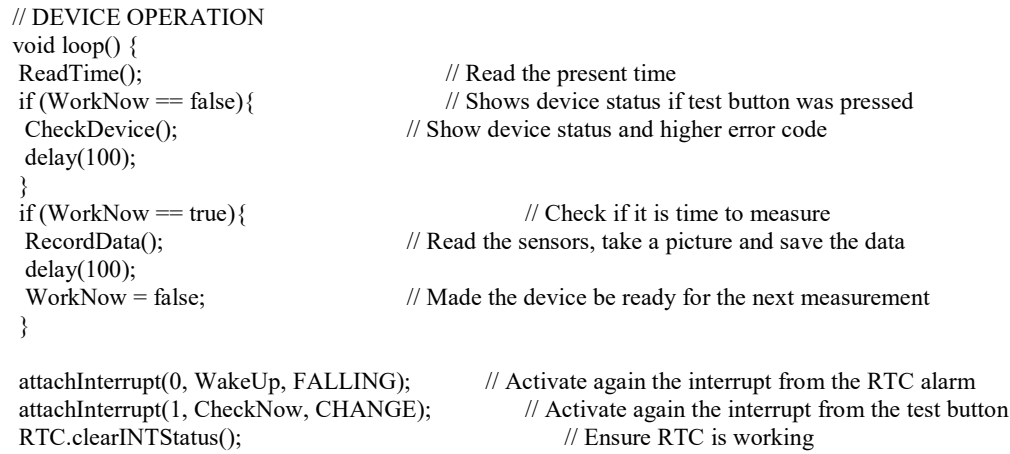

datafile = SD.open(filename1, FILE_WRITE); $\quad$ // Open the file to store the data

datafile.print $(2 *(\operatorname{readVcc}() *$ batt $) / 1023) ; \quad$ // Save the battery voltage (in volts)

// Turn on the sensor's power

// Give time to sensors to stabilize their reading

// Update measurement counter
// Try to open the datafile

// Save present day

// Save present month

// Save present year

// Check if RTC is up to date

// Error \#02: RTC is out of date

// Save present hour

// Save present minute

// Save present second

// Save measurement number (counter)

// Read and save microcontroler volt-age

// Read and save microcontroler inner temperature

// Read the battery voltage

// Save battery voltage (raw)

// Read the solar cell voltage

// Save solar cell voltage (raw)

// Save solar cell voltage (in volts) 


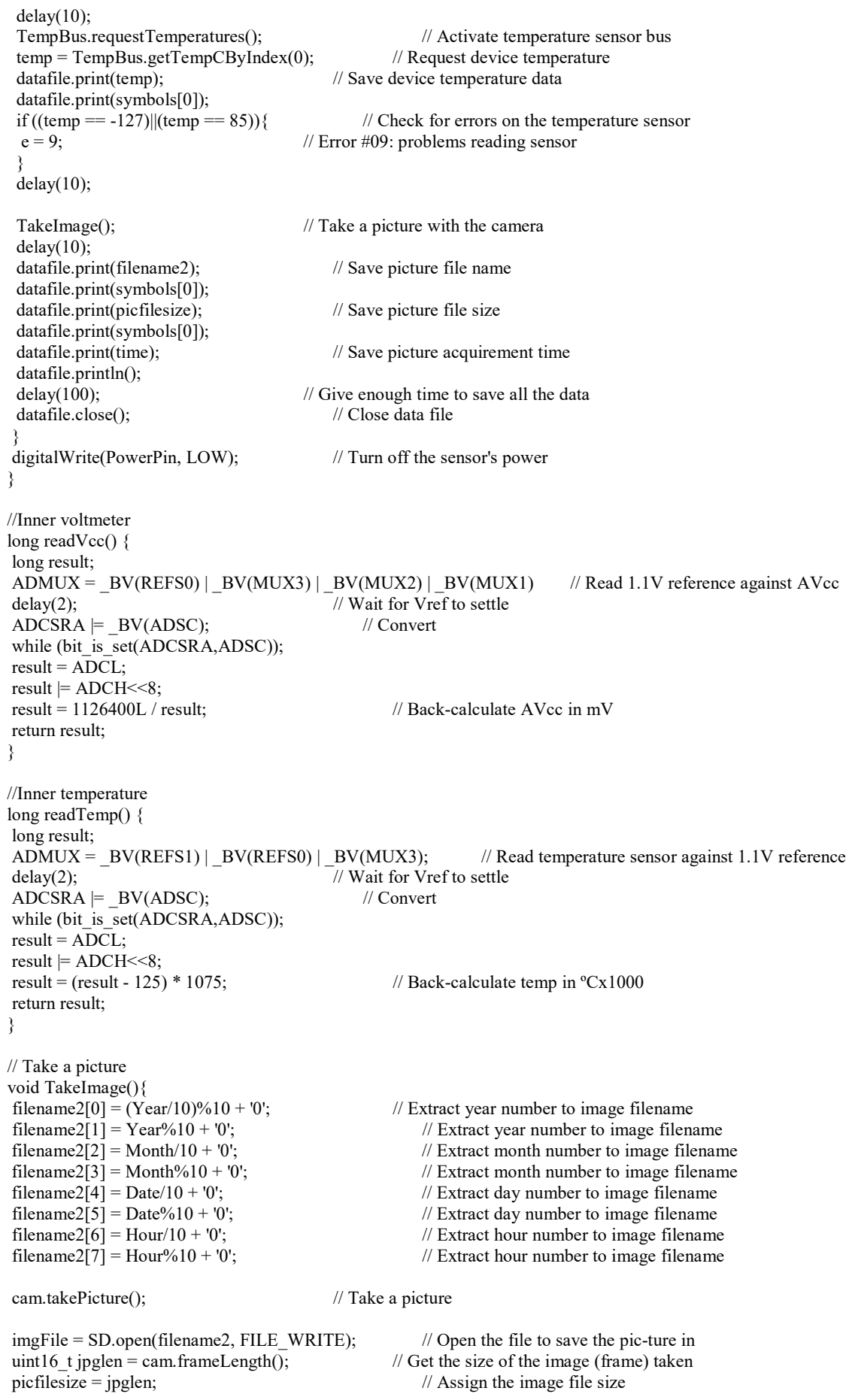




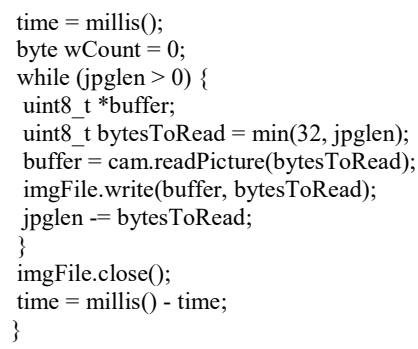

// Alarm stops the sleep process void WakeUp()

// Shows the device status by a blinking led void CheckDevice()\{

blinkLed(TestLedPin, 3, 500); delay(100);

blinkLed(TestLedPin, e, 200);

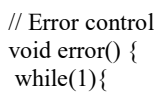

// Initialize a timecounter

// For counting \# of writes

// Check if there is image data to be saved

// Read 32 bytes at a time;

// Readd image bytes

// Buffer image data

// Transfer data to the imagefile

// Calculate remaining image bytes

// Close the image file

// Stop the time counter

// Disable interrupts to not disrupt the sensor readings // The device is ready to take new sensors readings

// Disable interrupts to not disrupt the de-vice checking // The device could be checked now
// Read date and time from the RTC
// Read year information from the RTC
// Read month information from the RTC
// Read day information from the RTC
// Read hour information from the RTC
// Read minute information from the RTC
// Read second information from the RTC

// Enables the sleep bit in the microcontroler register

// Put the microcontroller in sleep mode

// Disable sleep when the device is getting up 
blinkLed(TestLedPin, e, 200);

delay(1000);

\}

// Utility function to print numbers leading 0

void printDigits(int digits) \{

if $($ digits $<10)\{$

datafile.print $\left({ }^{\prime}{ }^{\prime}\right)$;

\}

datafile.print(digits);

\}

Polígonos. Revista de Geografia, 28 (2016); 161-181 